\title{
乳牛の疾病に関する疫学的研究
}

堀北哲也* ·林谷秀樹* - 小川益男 * 星野邦夫* ·香本頴利**

\section{Epidemiological studies on bovine diseases.}

\author{
Tetsuya HORIKITA ${ }^{1)}$, Hideki HAYASHIDANI ${ }^{1)}$, Masuo OGAWA ${ }^{1)}$, \\ Kunio HOSHINO'), and Hide-michi KOMOTO')
}

1) Faculty of agriculture, Tokyo university of Agriculture and Technology, 3-5-8 Saiwai-cho, Fuchu, Tokyo 183

2) Chiba Agricultural Insurance Associations, 3-2-6 Shin Chiba, Chiba, Chiba 260

\section{Summary}

From April 1980 to March 1983, 69 farms in Chiba prefecture were studied on a correlation between incidence rates of bovine diseases and climatologic factors. From the socio-demographic and management with diseases were drawn out by the method of Quantitative Model III. Correlations between the important factors and the incidence rates were analysed by the method of Quantitative Model I. The results obtained are as follow.

1. There was generally a positive correlation between the monthly incidence rates of "All-disease" and "mastitis", and the mean monthly temperature and humidity $(\mathrm{p}<0.05)$. The incidence rates of "reproductive disorder" and "infertility", however, were not associated with such climatic factors. These results suggested that effect of climatic factors such as temperature and humidity depended on the diseases.

2. A correlation between the incidence rate of "all-disease" and environmental factors was analysed by the method of Quantitative Model I. The results showed that the incidence rates of "all-disease" tend to be higher at large scale farms run by young full-time managers intending to increase milk production.

3. The incidence rates of "reproductive disorder" were more strongly associated with managemetal factors, especially with the age of manager and the presence of successor than were that of the other diseases. It tended to be low at farms managed by older men having longer experience.

4. The incidence rates of "infertility" were associated with the factors concerned with management, burn-environments and burn-structures and tended to be higher at the farms having bad burn-environments. It seemed to be higher at the farms managed by young men eager to have a higher boost of milk production.

5. The incidence rates of "mastitis" were associated with the factors concerned with burnenvironments and -structures especially with ditch and feeding structures. It tended to be high at the large scale farms managed by the men attempting to increase milk production. 
乳牛の疾病の発生には, 自然環境要因や人為環境 要因など多くの要因が複雑に関与している3)。疾病 の発生とこれらの要因との関連の度合を総合的に検 討し, 疾病の発生に奇与する主要要因をさぐりだす ことは, 疾病の発生予防対策を考える上で極めて重 要なことである。

乳牛の疾病の発生に影響を及ほす自然環境要因の うちでは，とくに気温や気湿などの気象要因が重視 されている。これまでにも Simesen (1974) ${ }^{9)}$ が気温 と乳房炎および産莀麻疸との関連性を, 桝田ら $(1979)^{7)}$ が気温, 気湿および気圧と消化器病などと の関連性を報告している。

しかし，気象要因と疾病の関係についてのこれま

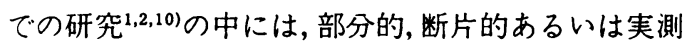

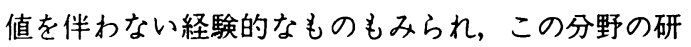
究はあまり進んでいないといえる。そこで本研究は， 乳牛に多発している疾病を選び, 広く気象要因との 関係を比較検討することを目的として, 乳牛の主要 な疾病のリ患率と各種気象要因の測定值との相関関 係を調べた。

また, 乳牛の疾病の発生には, 経営, 飼養, 飼料 および畜舎などの人為環境要因（酪農環境要因）が 強く影響しているとの報告 ${ }^{3)}$ もある。これらの酪農 環境要因の多くは，質的データとして記述せざるを 得ないこともあって, 乳牛の疾病と酪農環境要因と の関斬性を詳細に解析した報告は極めて少ない3)。 星野 (1978) ${ }^{5}$ は, 乳房炎の発生と酪農環境要因との 関連性を, 質的データの解析法として開発された林 の数量化理論 (I, II, III類 $\left.{ }^{4}\right)$ をを用いて解析してい る。本研究においては, 乳牛の各種疾病の発生と, 主として質的に記述された酪農環境要因との関連性 を, 数量化理論 I ・III類により解析し, 各種疾病の 発生に及ほす酪農環境要因の影響について整理した。

\section{資料およびデータ解析}

\section{1. 資料}

千葉県農業共済組合連合会家畜臨床研修所管内の 酪農家を, 飼育成乳牛の頭数によって, $1 \sim 5$ 頭, $6 \sim 10$ 頭, $11 \sim 15$ 頭, $16 \sim 20$ 頭, $21 \sim 25$ 頭, $26 \sim 30$ 頭および31頭以上の 7 グループに分けた。各グルー プからそれぞれ10戸（ただし31頭以上は 9 戸）の計 69戸を無作為に抽出し調查対象酪農家とした。

これらの酪農家について，表 1 に示す各疾病のリ 患率を, 昭和 55 年度から 57 年度の 3 ケ年にわたり調 查した。リ患率は次式により求めた。

\section{表 1 疾病の分類}

$\begin{array}{ll}\text { 1. } & \text { 伝染病 } \\ 2 . & \text { 寄生虫病 } \\ 3 . & \text { 血液および代謝疾患 } \\ 4 . & \text { 消化器病 } \\ 5 . & \text { 呼吸器病 } \\ 6 . & \text { 循環器病 } \\ 7 . & \text { 産科疾患 } \\ \text { 8. } & \text { 泌尿器の疾患 } \\ \text { 9. } & \text { 不妊症 } \\ 10 . & \text { 乳房炎 } \\ 11 . & \text { 運動器病 } \\ 12 . & \text { 神経系の疾患 } \\ 13 . & \text { その他 }\end{array}$

リ患率（年間または月間）

$$
=\frac{\text { 年間 (月間) 延べリ患頭数 }}{\text { 年間成乳牛頭数 }} \times 100
$$

また, 対象酪農家を訪問し, 酪農環境要因を実地 調查した。調査項目は, 経営, 搾乳, 乳量, 乳質, 飼料, 飼養, 予防衛生, 牛舎環境および牛舎構造に 関する98項目とした。

さらに，調查地域に近い牛久地区アメダス（地域 気象観測システム)によって観測された昭和 55 年度 から 57 年度の気象デー夕を千葉県気象月報より求め た。その具体的内容は月別平均気温, 月別最高気温, 月別最低気温, 月別降水量, 降水 $1 \mathrm{~mm}$ 以上の月間 累積日数, 月別日照時間, 日照時間 0.1 時間未満の月 別累積日数, 月別平均風速および月別平均湿度の 9 項目である。

\section{2.デー夕解析法}

東京大学大型計算機センターの BMDP, PPSS II のプログラムによって以下の解析を行った。

なお，解析の对象には表 1 の疾病のうち，リ患率 の高かった「産科疾患」、「不妊症」および「乳房炎」 と「全疾病」を選んだ。

\section{1 ) 疾病のリ患率と気象要因の関連性の解析}

昭和 55 年度から 57 年度の各年度について, 各疾病 の月別り患率と月別各気象データ間の関連性を調べ るために，而者の相関関係を検討した。

\section{2 ）疾病のリ患率と酪農環境要因の関連性 \\ (1) 疾病のリ患率に関連の強い酪農環境要因の抽出} 酪農家69戸を戸別訪問して調査した酪農環境要因 
98項目から，傊值をもつ28項目を除いて，70項目 のデータを選んだ。さらにこの70項目について，数 量化理論III類を応用して, 変動幅が少なく説明力が 弱いと思われる項目を除去し，説明力の強い項目の 抽出を試みた。

しかしこの方法で，今回の調査項目のすべてを同 時に解析するには, 調查農家数との関係上項目数が 多すぎる4)。そこで，調査項目を第 1 群（経営, 搾 乳，乳量，飼料に関する 4 事項34項目) と第 2 群(飼 養方法, 予防衛生, 牛舎環境, 牛舎構造に関する 4 事項36項目）に分けて，数量化理論III類を用い，そ れらの項目の持つ情報を少数の絵合的特性值（主成 分）に要約（抽出）することを試みた。得られた主 成分のうち，使用した全ての項目と最も高い相関を 示す特性值（すなわち奇与率が最も大きい主成分， 第一主成分) は, 第 1 群では, 規模, 専業度, 経営 者の年令などと, また第 2 群では環境などと強い関 連を示した。この関連の程度は, 各項目のカテゴリ 一に与えられたノーマライズドスコアで示される。 つまり，ノーマライズドスコアのレンジの大きい項 目ほど主成分との関連が強いことになる。このこと を考虑して，ここでは第 1 群と第 2 群の計70項目の 中からレンジが 3.0 以上の值を示す 24 項目を選んだ。 さらに,レンジが 3.0 未満のものでも, 経験上解析結 果の考察に重要と考之られる9項目を加之計33項目 とした。これらを表 2 に示す 5 事項に分けて以下の 解析に供した。

\section{2) 各疾病のリ患率と各事項の重相関分析}

「全疾病」、「産科疾患」,「不妊症」および「乳房炎」 のリ患率と各事項の重相関係数, 各調查項目 (表 2) との偏相関係数および各カテゴリーのノーマライズ ドスコアを知る目的で, 年度別, 事項別に数量化理 論 I 類による重相関分析を行った。

ここで，重相関係数はリ患率と各事項の関連の度 合を，偏相関係数はり患率に寄与する各調査項目の 強さを示している。また，ノーマライズドスコアは リ患率に及ばす各カテゴリーの相対的な影響の強さ を示している。

\section{成績および考察}

一般に, 乳牛とくにホルスタイン種は耐暑性に劣 り耐寒性に優れ, 疾病の発生も夏に多いといわれて いる ${ }^{8)}$ 。

本研究では，まず調査地域の乳牛でリ患率の高か った「産科疾患」「「不妊症」および「乳房炎」と「全 疾病」のリ患率について各気象要因との関係を調べ
表 2 選択された酪農家調査項目

\section{1 経営に関する事項}

1 耕地面積

2 自作草地面積

3 経営年数

4 経営者の年令

5 後継者の有無

6 酪農専業度

7 経産牛

8 未経産牛

9 従事者数

10 経営規模の変更

\section{2 搾乳に関する事項}

11 搾乳方法

12 ミルカー台数

13 搾乳時間

14 乾乳期間

15 年間総出荷乳量

16 目標乳量

\section{3 飼養管理に関する事項}

17 給餌回数

18 放牧・繫牧

19 年間淘汰廃用頭数

20 乳頭損傷の予防

4 牛舎の環境及び構造に関する事項

21 牛舎の通気性

22 牛舎の照度

23 牛床の乾燥度

24 牛床の排水性

25 排水溝の構造

26 飼槽の形式

27 牛床の長さ

\section{5 飼料に関する事項}

28 給与濃厚飼料に占好る 市販配合飼料の割合

29 食品粕給与の有無

30 青刈りコーン, ソルゴーの給与

31 根菜類の給与

32 サイレージの給与

33 ビートパルプの給与 
た。その結果,「全疾病」と気温, 気湿との間で有意 の相関が認められた(表 3 )。このことは, 乳牛の疾 病が全般的に夏に多く冬に少ないという常識を，実 測值により証明したことになる。

「乳房炎」についても, 全年度を通じて, 気温, 気 湿との間で有意の相関がみられることが実証された。 これは, 気温, 気湿が高くなる夏に，乳房炎のリ患 率が高くなるためである。つまり, 気温, 気湿の高 い夏には, 乳牛の生理機能が減退して抵抗力が弱ま $\eta^{6)}$, かつ乳房炎の起因菌が牛床や搾乳器内で増殖 しやすく感染の機会が增すことによる。

また，「全疾病」および「乳房炎」のリ患率と降水 量，日照時間および風速との間には有意の相関はみ られない。以上のことよりこれらの疾病の発生に影 響を及ばす気象要因としては，とくに気温と気湿が 重要であると考えられる。

「産科疾患」と「不妊症」は, 各気象要因との間で 有意の相関を示さなかった。これらの疾病は，先の 2 疾病にくらべ, 気象要因による影響よりも他の要 因による影響が大きいと考えられる。

次に本研究では, 各疾病のリ患率と酪農環境要因 との関連をみるために数量化理論 I 類を応用し重相 関分析を行った。

表 4 は経営に関する事項と, 表 5 は搾牛に関する 事項と, 表 6 は飼養管理に関する事項と, 表 7 は牛
舎の環境・構造に関する事項と,そして表 8 は飼料 に関する事項と各疾病との関連を示したものである。 すなわち, 各事項と各疾病のリ患率の関連を, 年度 別に数量化理論 I 類により分析して得られた重相関 係数，偏相関係数およU゙ノーマライズドスコアを示 した。ただし，偏相関係数が各疾病ともに小さく疾 病への関連が低いと考えられる項目は表に記載しな かった。

まず，「全疾病」を中心に調查項目との関連性を検 討する。

酪農専業度「 $100 \%$, 経産牛数「31頭以上」およ び搾乳方法「パイプライン」など規模が大きいこと を示すカテゴリーが，リ患率の増加に作用していた

(表 4，5)。これは, 規模が大きくなり多頭化がす すむにつれて，疾病の発生が增すというこれまでの 報告 ${ }^{11}$ に一致している。運動場への放牧「する」は, このカテゴリーに該当する酪農家 6 戸のうち 5 戸が 酪農専業度「100\%」であるにもかかわらず，リ患率 の減少に作用していた（表 6 )。この傾向は「産科疾 患」および「不妊症」でもみられ，これらの疾病で は運動場への放牧が牛体に良い影響を与えているこ とが実証された。しかし、「乳房炎」では運動場への 放牧「する」がリ患率の增加に作用している。これ は運動場が污染されていて感染の機会が增大するこ となどの原因によると考えられる。

表 3 各疾病のリ患率（月別）と気象要因（月別）の相関係数

\begin{tabular}{cccccc}
\hline 疾病 & 年度 & 月別平均気温 & 月別最高気温 & 月別最低気温 & 月別平均湿度 \\
\hline 全 & 55 & $0.679^{*}$ & $0.676^{*}$ & $0.680^{*}$ & $0.680^{*}$ \\
疾 & 56 & $0.897^{* *}$ & $0.912^{* *}$ & $0.885^{* *}$ & $0.754^{* *}$ \\
病 & 57 & $0.646^{*}$ & $0.598^{*}$ & $0.638^{*}$ & $0.695^{*}$ \\
\hline 産 & 55 & -0.164 & 0.003 & -0.020 & -0.201 \\
科 & 56 & 0.049 & 0.070 & 0.043 & -0.079 \\
疾 & 57 & 0.279 & 0.290 & 0.291 & 0.301 \\
\hline 不 & 55 & 0.531 & 0.525 & 0.517 & $0.596^{*}$ \\
姡 & 56 & 0.440 & 0.448 & 0.430 & 0.209 \\
症 & 57 & 0.393 & 0.388 & -0.255 & 0.408 \\
\hline 乳 & 55 & $0.620^{*}$ & $0.611^{*}$ & $0.642^{*}$ & $0.610^{*}$ \\
房 & 56 & $0.847^{* *}$ & $0.865^{* *}$ & $0.852^{* *}$ & $0.825^{* *}$ \\
炎 & 57 & $0.732^{* *}$ & $0.735^{* *}$ & $0.725^{* *}$ & $0.829^{* *}$ \\
\hline
\end{tabular}

注. $\mathrm{t}$ 検定により*は危険率 $5 \%$ ，**は危険率 $1 \%$ で有意 
表 4 各疾病のリ患率と経営に関する事項の重相関分析

\begin{tabular}{|c|c|c|c|c|c|c|c|c|c|c|c|c|c|c|}
\hline \multirow{2}{*}{ 調査項目 } & \multirow{2}{*}{ カテゴリー } & \multirow{2}{*}{ 戸数 } & \multicolumn{3}{|c|}{ 全疾病 } & \multicolumn{3}{|c|}{ 産科疾患 } & \multicolumn{3}{|c|}{ 不妊症 } & \multicolumn{3}{|c|}{ 乳房炎 } \\
\hline & & & $55^{*}$ & 56 & 57 & 55 & 56 & 57 & 55 & 56 & 57 & 55 & 56 & 57 \\
\hline 経営者 & 40才未満 & 19 & 52.4 & 34.2 & 23.2 & 11.6 & 3.9 & 13.8 & 16.6 & 10.1 & 0.2 & 4.5 & 14.9 & 3.7 \\
\hline \multirow[t]{3}{*}{ の年齢 } & $40 オ \sim 60 オ$ & 38 & -15.3 & -7.6 & -12.7 & -1.6 & 0.1 & -5.3 & -3.7 & -3.4 & -4.0 & -2.7 & -2.4 & -1.2 \\
\hline & 60 オ以上 & 12 & -30.6 & -30.3 & 3.4 & -12.9 & -6.5 & -4.4 & -13.6 & -5.1 & 12.3 & 1.4 & -16.1 & -2.0 \\
\hline & & & $(0.350)$ & $(0.299)$ & $(0.260)$ & $(0.396)$ & $(0.202)$ & $(0.390)$ & $(0.329)$ & $(0.260)$ & $(0.324)$ & $(0.135)$ & $(0.279)$ & $(0.092)$ \\
\hline 後継者 & 本人** & 23 & -21.2 & -9.9 & -17.0 & -7.0 & -4.4 & -10.4 & -2.9 & 5.0 & 5.1 & -1.9 & -7.8 & -3.0 \\
\hline \multirow[t]{4}{*}{ の有無 } & いる & 17 & 37.9 & 8.6 & 12.6 & 10.6 & 6.5 & 13.9 & 8.7 & 4.0 & -8.3 & 5.2 & 8.0 & -9.0 \\
\hline & いない & 14 & -6.8 & -7.9 & 4.3 & -3.6 & 2.3 & 4.3 & -6.9 & -7.1 & 4.2 & -4.8 & -8.0 & -5.5 \\
\hline & 未定 & 15 & -5.7 & 12.9 & 7.8 & 1.9 & -2.8 & -3.9 & 1.4 & -5.5 & -2.3 & 1.5 & 10.4 & 10.7 \\
\hline & & & $(0.296)$ & $(0.171)$ & $(0.211)$ & $(0.426)$ & $(0.303)$ & $(0.474)$ & $(0.206)$ & $(0.213)$ & $(0.312)$ & $(0.163)$ & $(0.278)$ & $(0.262)$ \\
\hline 酪農専 & $50 \%$ 以下 & 16 & 9.2 & -2.4 & -12.3 & -1.8 & -7.9 & 7.6 & 8.8 & 11.5 & -5.4 & 2.7 & -5.3 & -7.7 \\
\hline \multirow[t]{3}{*}{ 業度 } & $51 \sim 99 \%$ & 21 & -13.9 & -2.7 & 6.0 & -4.5 & 3.5 & 0.5 & -13.1 & -9.0 & 0.3 & -2.2 & -5.1 & 1.8 \\
\hline & $100 \%$ & 32 & 4.6 & 3.0 & 2.2 & 3.7 & 1.6 & -4.1 & 4.4 & 0.2 & 2.5 & 0.1 & 6.0 & 2.7 \\
\hline & & & $(0.169)$ & $(0.054)$ & $(0.160)$ & $(0.277)$ & $(0.300)$ & $(0.274)$ & $(0.373)$ & $(0.334)$ & $(0.150)$ & $(0.081)$ & $(0.212)$ & $(0.191)$ \\
\hline \multirow[t]{5}{*}{ 経産牛 } & 10頭以下 & 18 & 0.6 & 10.5 & -26.9 & 0.6 & 0.5 & -9.8 & 5.7 & 16.3 & -2.6 & -5.4 & 0.3 & -2.9 \\
\hline & 11～20頭 & 27 & 15.9 & $6: 0$ & 15.2 & -0.2 & 0.7 & 2.5 & 8.1 & -2.2 & 2.9 & 2.9 & 6.4 & 0.8 \\
\hline & $21 ３ 0$ 頭 & 15 & -31.6 & -29.9 & -6.0 & -2.2 & -4.1 & 1.7 & -13.2 & -6.8 & -0.1 & -7.1 & -11.2 & -3.0 \\
\hline & 31頭以上 & 9 & 5.7 & 16.0 & 21.4 & 3.3 & 4.8 & 10.1 & -13.8 & -15.6 & -3.5 & 16.7 & 0.2 & 9.9 \\
\hline & & & $(0.280)$ & $(0.321)$ & $(0.368)$ & $(0.128)$ & $(0.203)$ & $(0.326)$ & $(0.302)$ & $(0.354)$ & $(0.137)$ & $(0.292)$ & $(0.249)$ & $(0.154)$ \\
\hline \multicolumn{2}{|c|}{ 重相関係数 } & & 0.477 & 0.452 & 0.509 & 0.636 & 0.562 & 0.589 & 0.515 & 0.666 & 0.581 & 0.391 & 0.426 & 0.372 \\
\hline
\end{tabular}

表 5 各疾病のリ患率と搾乳に関する事項の重相関分析

\begin{tabular}{|c|c|c|c|c|c|c|c|c|c|c|c|c|c|c|}
\hline \multirow{2}{*}{ 調査項目 } & \multirow{2}{*}{ カテゴリー } & \multirow{2}{*}{ 戸数 } & \multicolumn{3}{|c|}{ 全疾病 } & \multicolumn{3}{|c|}{ 産科疾患 } & \multicolumn{3}{|c|}{ 不妊症 } & \multicolumn{3}{|c|}{ 乳房炎 } \\
\hline & & & 55 & 56 & 57 & 55 & 56 & 57 & 55 & 56 & 57 & 55 & 56 & 57 \\
\hline \multirow[t]{4}{*}{ 㩁乳方法 } & 手搾り & 2 & -16.5 & 43.9 & -4.3 & -6.2 & -0.7 & 15.7 & 47.6 & 37.0 & -4.9 & -27.0 & 26.0 & 1.4 \\
\hline & バケット & 31 & -12.9 & -12.3 & -2.6 & -4.4 & 5.2 & 2.3 & -2.8 & -2.3 & 5.8 & -6.6 & -13.0 & -5.5 \\
\hline & パイプライン & 36 & 12.4 & 8.2 & 2.5 & 4.3 & -4.4 & -2.8 & -0.1 & -0.1 & -4.8 & 7.2 & 9.8 & 4.7 \\
\hline & & & $(0.127)$ & $(0.228)$ & $(0.063)$ & $(0.217)$ & $(0.279)$ & $(0.063)$ & $(0.329)$ & $(0.307)$ & $(0.206)$ & $(0.254)$ & $(0.342)$ & $(0.218)$ \\
\hline \multirow[t]{4}{*}{ 目標乳量 } & 特になし & 12 & -49.4 & -35.7 & -6.9 & -0.4 & -0.8 & 0.9 & -7.4 & -6.3 & -1.0 & -12.3 & -9.0 & 1.0 \\
\hline & $6500 \mathrm{~kg}$ 以下 & 30 & 9.3 & -14.8 & -2.8 & 1.0 & 0.2 & 2.1 & 0.7 & -8.2 & -1.0 & -1.1 & -1.9 & -3.6 \\
\hline & $6501 \mathrm{~kg}$ 以上 & 27 & 10.5 & 32.3 & 6.1 & -0.9 & 0.2 & -2.7 & 2.3 & 12.0 & 1.4 & 6.7 & 6.1 & 3.5 \\
\hline & & & $(0.333)$ & $(0.473)$ & $(0.133)$ & $(0.065)$ & $(0.029)$ & $(0.133)$ & $(0.137)$ & $(0.404)$ & $(0.058)$ & $(0.297)$ & $(0.217)$ & $(0.171)$ \\
\hline \multicolumn{3}{|c|}{ 重相関係数 } & 0.350 & 0.515 & 0.497 & 0.409 & 0.455 & 0.420 & 0.436 & 0.566 & 0.424 & 0.436 & 0.387 & 0.456 \\
\hline
\end{tabular}

表 6 各疾病のリ患率と飼養管理に関する事項の重相関分析

\begin{tabular}{|c|c|c|c|c|c|c|c|c|c|c|c|c|c|c|}
\hline \multirow{2}{*}{ 調査項目 } & \multirow{2}{*}{ カテゴリー } & \multirow{2}{*}{ 戸数 } & \multicolumn{3}{|c|}{ 全疾病 } & \multicolumn{3}{|c|}{ 産科疾患 } & \multicolumn{3}{|c|}{ 不姡症 } & \multicolumn{3}{|c|}{ 乳房炎 } \\
\hline & & & 55 & 56 & 57 & 55 & 56 & 57 & 55 & 56 & 57 & 55 & 56 & 57 \\
\hline 運動場へ & しない & 42 & 4.4 & 4.6 & -0.2 & 0.4 & 3.0 & 1.9 & 0.1 & 1.2 & -0.1 & -1.4 & -4.1 & -2.9 \\
\hline \multirow[t]{3}{*}{ の放牧 } & 時々する & 21 & -6.8 & -6.6 & 1.0 & 0.3 & -3.6 & -1.5 & 3.0 & -1.3 & 0.5 & -2.4 & 1.4 & 1.7 \\
\hline & する & 6 & -7.2 & -9.3 & -1.9 & -4.0 & -8.1 & -8.1 & -11.2 & -4.0 & -0.6 & 18.0 & 23.8 & 14.1 \\
\hline & & & $(0.086)$ & $(0.119)$ & $(0.021)$ & $(0.081)$ & $(0.211)$ & $(0.211)$ & $(0.149)$ & $(0.070)$ & $(0.017)$ & $(0.262)$ & $(0.323)$ & $(0.245)$ \\
\hline \multicolumn{2}{|l|}{ 重相関係数 } & & 0.234 & 0.402 & 0.381 & 0.212 & 0.406 & 0.433 & 0.240 & 0.364 & 0.248 & 0.316 & 0.415 & 0.416 \\
\hline
\end{tabular}


表 7 各疾病のリ患率と牛舎の環境および構造に関する事項の重相関分析

\begin{tabular}{|c|c|c|c|c|c|c|c|c|c|c|c|c|c|c|}
\hline \multirow{2}{*}{ 調査項目 } & \multirow{2}{*}{ カテゴリー } & \multirow{2}{*}{ 戸数 } & \multicolumn{3}{|c|}{ 全疾病 } & \multicolumn{3}{|c|}{ 産科疾患 } & \multicolumn{3}{|c|}{ 不妊症 } & \multicolumn{3}{|c|}{ 乳房炎 } \\
\hline & & & 55 & 56 & 57 & 55 & 56 & 57 & 55 & 56 & 57 & 55 & 56 & 57 \\
\hline 牛舎の & 悪 & 20 & 7.1 & -15.8 & -22.4 & 1.6 & 0.4 & -2.1 & 2.6 & 4.9 & 0.8 & -1.3 & -11.3 & -12.4 \\
\hline \multirow[t]{3}{*}{ 通気性 } & 普 通 & 36 & -5.3 & 1.9 & 6.5 & -1.3 & -0.6 & 2.2 & 1.9 & 1.7 & 3.2 & -0.7 & 5.0 & 4.6 \\
\hline & 良い & 13 & 3.7 & 19.0 & 16.4 & 1.2 & 1.0 & -2.9 & -9.2 & -12.3 & -10.0 & 3.9 & 3.6 & 6.5 \\
\hline & & & $(0.102)$ & $(0.185)$ & $(0.345)$ & $(0.097)$ & $(0.045)$ & $(0.156)$ & $(0.145)$ & $(0.163)$ & $(0.223)$ & $(0.074)$ & $(0.326)$ & $(0.343)$ \\
\hline 排水溝 & 哚い溝 & 39 & 11.8 & -0.7 & 4.2 & -0.7 & -0.5 & 0.6 & 3.9 & 1.8 & 2.5 & 0.4 & 2.9 & 0.4 \\
\hline \multirow[t]{6}{*}{ の構造 } & 排水溝なし & 10 & 4.6 & 13.4 & 12.5 & -9.5 & -2.8 & -1.1 & 11.4 & 6.4 & 11.0 & 3.0 & 5.5 & 3.9 \\
\hline & ロストル & 5 & -27.8 & -14.2 & -11.4 & 10.2 & -3.4 & -7.2 & -17.3 & -4.9 & -13.1 & 9.9 & 8.6 & 17.8 \\
\hline & バンクリーナー & 6 & 1.2 & 3.5 & -16.0 & 12.1 & 0.2 & -3.3 & 3.5 & -0.2 & -17.7 & -5.8 & -4.6 & -0.9 \\
\hline & マンホール & 3 & 15.8 & 14.5 & 14.1 & 8.4 & 7.3 & 12.8 & 16.6 & 27.7 & 4.3 & 7.1 & -8.3 & -16.1 \\
\hline & 浅い溝 & 6 & -70.6 & -16.8 & -29.9 & -4.4 & 6.6 & 1.0 & -41.5 & -32.1 & -8.5 & -13.4 & -26.9 & -15.1 \\
\hline & & & $(0.403)$ & $(0.182)$ & $(0.295)$ & $(0.355)$ & $(0.192)$ & $(0.229)$ & $(0.543)$ & $(0.415)$ & $(0.430)$ & $(0.264)$ & $(0.400)$ & $(0.359)$ \\
\hline 飼槽の & 溝 型 & 31 & -7.0 & -10.6 & 6.4 & -2.2 & 0.9 & 0.9 & -1.2 & 1.0 & 11.3 & -7.9 & -8.8 & -6.3 \\
\hline \multirow[t]{3}{*}{ 形式 } & 床 型 & 16 & -10.1 & -8.7 & -16.5 & 1.2 & -0.2 & -5.7 & 0.6 & -14.5 & -13.5 & -0.8 & -1.1 & 0.4 \\
\hline & 桶 型 & 22 & 2.6 & 21.2 & 3.0 & 2.2 & -1.1 & 2.9 & 1.3 & 9.1 & -6.2 & 11.8 & -13.2 & 8.5 \\
\hline & & & $(0.127)$ & $(0.297)$ & $(0.234)$ & $(0.129)$ & $(0.058)$ & $(0.229)$ & $(0.054)$ & $(0.344)$ & $(0.539)$ & $(0.382)$ & $(0.420)$ & $(0.307)$ \\
\hline 牛床の & $190 \mathrm{~cm}$ 以下 & 31 & 8.1 & 5.0 & 3.1 & -2.3 & -1.1 & -3.3 & -1.6 & -4.8 & 5.1 & 5.9 & 5.2 & 1.6 \\
\hline \multirow[t]{3}{*}{ 長さ } & $191 \sim 230 \mathrm{~cm}$ & 20 & -20.2 & -6.5 & -8.8 & -0.8 & -2.5 & -2.2 & -2.5 & -1.5 & -2.3 & -3.2 & 1.6 & 0.3 \\
\hline & $231 \mathrm{~cm}$ 以上 & 18 & 8.5 & -1.3 & 4.6 & 4.8 & 4.8 & 8.2 & 5.5 & 9.9 & -6.3 & -6.6 & -10.7 & -3.1 \\
\hline & & & $(0.229)$ & $(0.107)$ & $(0.156)$ & $(0.192)$ & $(0.205)$ & $(0.346)$ & $(0.150)$ & $(0.250)$ & $(0.298)$ & $(0.260)$ & $(0.312)$ & $(0.103)$ \\
\hline \multicolumn{3}{|c|}{ 重相関係数 } & 0.490 & 0.413 & 0.492 & 0.467 & 0.391 & 0.482 & 0.570 & 0.489 & 0.657 & 0.502 & 0.641 & 0.510 \\
\hline
\end{tabular}

表 8 各疾病のリ患率と飼料に関する事項の重相関分析

\begin{tabular}{|c|c|c|c|c|c|c|c|c|c|c|c|c|c|c|}
\hline \multirow{2}{*}{ 調查項目 } & \multirow{2}{*}{ カテゴリー } & \multirow{2}{*}{ 戸数 } & \multicolumn{3}{|c|}{ 全疾病 } & \multicolumn{3}{|c|}{ 産科疾患 } & \multicolumn{3}{|c|}{ 不妊症 } & \multicolumn{3}{|c|}{ 乳房炎 } \\
\hline & & & 55 & 56 & 57 & 55 & 56 & 57 & 55 & 56 & 57 & 55 & 56 & 57 \\
\hline 濃厚飼料 & $0 \%$ & 9 & 9.4 & 7.6 & 18.5 & 0.0 & -1.1 & 5.6 & 1.6 & -3.2 & -1.7 & 6.9 & 10.6 & 5.4 \\
\hline に占める & $1 \sim 25 \%$ & 18 & 15.4 & 4.7 & -5.0 & 2.1 & -0.5 & -1.0 & 7.2 & 8.6 & -4.7 & 2.2 & 2.1 & -1.4 \\
\hline 市販配合 & $26 \sim 50 \%$ & 35 & -2.0 & 7.5 & -0.6 & -0.4 & 2.2 & -1.0 & -1.5 & 0.5 & 2.2 & -1.2 & -0.7 & 1.2 \\
\hline 飼料の割 & $51 \%$ & 7 & -43.0 & -59.2 & -8.0 & -3.6 & -8.3 & 0.3 & -14.0 & -20.8 & 3.1 & -8.6 & -15.6 & -9.3 \\
\hline 合 & & & $(0.266)$ & $(0.411)$ & $(0.200)$ & $(0.111)$ & $(0.225)$ & $(0.152)$ & $(0.241)$ & $(0.225)$ & $(0.165)$ & $(0.179)$ & $(0.273)$ & (0.195) \\
\hline 青刈りコ & しない & 18 & 18.5 & 7.6 & 1.9 & 4.0 & -2.7 & -4.0 & 9.3 & 1.5 & 2.6 & 9.7 & 12.8 & 9.0 \\
\hline ーン, ソ & 片方給与 & 17 & 5.7 & 3.2 & 4.5 & 6.8 & 3.1 & 2.7 & -3.2 & -4.9 & -5.5 & -1.6 & -0.0 & 1.7 \\
\hline ルゴーの & 両方給与 & 34 & -12.5 & -5.6 & -3.3 & -5.3 & -0.1 & 0.8 & -3.4 & 1.7 & 1.4 & -4.4 & -6.8 & -5.6 \\
\hline 給与 & & & $(0.189)$ & $(0.109)$ & $(0.085)$ & $(0.342)$ & $(0.139)$ & $(0.152)$ & $(0.184)$ & $(0.139)$ & $(0.171)$ & $(0.215)$ & $(0.304)$ & $(0.276)$ \\
\hline サイレー & しない & 33 & 7.1 & 7.8 & -9.3 & 2.3 & -0.5 & -0.6 & 1.0 & 3.2 & -4.7 & 0.6 & -4.1 & -4.8 \\
\hline \multirow[t]{3}{*}{ ジの給与 } & 季節により給与 & 22 & 2.0 & 5.6 & 17.0 & -2.2 & 1.8 & 0.5 & 1.8 & 0.6 & 6.5 & 2.1 & 11.5 & 7.3 \\
\hline & 通年給与 & 14 & -18.8 & -27.2 & -4.6 & -1.7 & -1.6 & 0.7 & -5.1 & -8.6 & 0.9 & -4.7 & -8.5 & -0.3 \\
\hline & & & $(0.147)$ & $(0.261)$ & $(0.294)$ & $(0.147)$ & $(0.091)$ & $(0.037)$ & $(0.090)$ & $(0.091)$ & $(0.250)$ & $(0.097)$ & $(0.327)$ & $(0.260)$ \\
\hline \multicolumn{3}{|l|}{ 重相関係数 } & 0.405 & 0.472 & 0.465 & 0.395 & 0.344 & 0.323 & 0.445 & 0.461 & 0.463 & 0.282 & 0.453 & 0.437 \\
\hline
\end{tabular}


経営者の年令「40才未満」および目標乳量「6501 $\mathrm{kg}$ 以上」がリ患率の增加に, 年令「 $40 \sim 60$ 才」「60才 以上」および目標乳量「特になし」がリ患率の減少 に作用しており（表 4,5 ), 生産意欲の旺盛な若い 酪農家において, 疾病の発生が増加する傾向にある。 「産科疾患」「「不妊症」および「乳房炎」について もほぼ同様の傾向がみられる。

後継者「本人」とした酪農家は，そのほとんどが 年令「40才未満」であるにもかかわらずリ患率の減 少に作用しており (表 4), 後継者であるという自覚 のもと，親の代より受け継いだ技術を適切に応用し て酪農経営にのぞんでいると考之られる。逆に, 後 継者「いる」とした酪農家は, その全てが年令「 40 ～60 才」または「60才以上」であるにもかかわらずリ患 率の増加に作用している(表 4)。これは, 後継者が まだ働き手となっていないことからの人手不足によ る管理失宜, 後継者への期待感からの無理な酪農経 営により疾病が増加するのではないかと考之られる。

牛舎環境および構造に関する事項（表 7 ）では, 牛舎の通気性「良い」は「全疾病」「産科疾患」拧 よび「乳房炎」についてリ患率の増加に作用してい るにもかかわらず，「不妊症」については減少に作用 している。通気性の良さは，ストレスの軽減や授精 後の体温の上昇を防ぐことなどにより、「不妊症」の リ患率を減少させる方向に作用すると考之られる。

排水溝の構造では, 牛床が䔬尿に污染されやすい と思われる排水溝「なし」や「マンホール」がリ患 率增加の傾向を，また比較的污染されにくい「ロス トル」で減少の傾向を示した。しかし，牛床が比較 的污染されやすい排水溝「浅い溝」は減少に作用し ていた。この理由として，このような酪農家は規模 が小さいためにリ患率が減少したと考えられる。

つぎに「産科疾患」では, 経営者の年令「40才未 満」, 経産牛「31頭以上」および目標乳量 $\ulcorner 6500 \mathrm{~kg}$ 以 下」がリ患率の增加に, 年令「60才以上」が減少に 作用していた(表 $4 ， 5$ )。すなわち規模が大きく目 標のあまり高くない若い酪農家で「産科疾患」の発 生が多く、経験豊富と思われる老路の酪農家で少な い傾向にある。

「不妊症」は, 他の事項にくらべ牛舎の環境および 構造に関する事項との関連が比較的強い。牛舎の通 気性「悪い」, 排水溝の構造「なし」,「マンホール」 上いった牛舎構造の悪さ走すカテゴリーが、リ患 率の増加に作用しているように思われた（表 7 ）。

最後に「乳房炎」も「不妊症」上同様に, 他の事
項にくらべ牛舎の環境および構造に関する事項との 関連が強かった。牛床が翼尿で污染されやすい排水 溝「なし」, 起立時に乳頭損傷をまねきやすく乳器が 䔬尿で污染されやすい牛床の長さ「 $190 \mathrm{~cm}$ 以下」，お よび食べ残した慨の掃除がしにくい「桶型飼槽」が リ患率の増加に作用していた。また掃除がしやすく 清潔に保てる「溝型飼槽」や「バンクリーナー」が, リ患率の減少に作用していることがうかがわれた (表 7 )。

年齢「40才未満」, 経産牛「31頭以上」, 目標乳量 $\ulcorner 6501 \mathrm{~kg}$ 以上」, 搾牛方法「パイプライン」および排 水溝の構造「ロストル」など, 若い経営者で規模が 大きく生産意欲旺盛であることを示すカテゴリーが, リ患率の増加に作用していた（表 4，5，7）。

以上, 各疾病のリ患率と調査項目 (酪農環境要因) との関連性を解析データにもとづいて考察してきた が, 各疾病のリ患率に及ぼす各項目の関与の状況に ついては，必ずしも鮮明に整理できないものもみら れた。

星野 (1978) 5)は, 乳房炎のリ患率と酪農環境要因 との関連性を数量化理論を用いて解析した。その結 果, 搾乳関係扩よび乳頭損傷関係の要因が最も重要 であることを示しており，今回の調査結果とは異な つていた。これは, 今回の調査時点では乳質改善の 良乳質の維持の必要性が一層高まり，乳頭損傷牛の 多くが陶汰処分される時代となっていたためと考之 られる。しかし，多変量解析法を用いたこの種の調 査はこれまでほとんど例がない。今後, 調査対象酪 農家の選択方法, 調査項目の設定, カテゴリーの分 類方法などと関連して，多変量解析法の適切な導入 方法についても，さらに様々な角度から試行錯誤を 重ね、デー夕を積み上げてゆく努力が望まれる。

\section{引用文献}

1) Burnside, E. B., Kowalchuck, S. B., Lambroughton, D. B. and MacLeod, N. M., (1971) ; Canadian dairy cow disposals. 1. Differences between breeds, lactation numbers and season., Can. J. Anim. Sci.51,75-83.

2 ) Dohoo, I. R. and Martin, S. W., (1984) ; Disease, prodution and culling in HolsteinFresian cows. II. Age, season and sire effects., Prev. Vet. Med., 2,655-670.

3 ) Dohoo, I. R., Martin, S. W. and Meek, A. H., (1984) ; Disease, production and culling in 
Holstein-Fresian cows.VI. Effect of management on disease rates., Prev. Vet. Med., 3,15 -28 .

4 ) 河口至商 (1973); 多変量解析入門 I, 森北出 版, 東京.

5 ）星野邦夫(1978)；ウシ乳房炎に関する疫学的研 究, 数量化理論による乳房炎流行の分析, 麻布 獣医大研報, 3，49-74.

6 ) 飯塚三喜, 久米常夫, 原茂, 野附㦑(1979)；牛 の乳房炎, 日本獣医師会, 東京.

7 ) 桝田智幸, 星欽弥 (1979)；気象の変化と牛疾病 発生の関連について(第一報), 紫葉, 24,23 29.

8 ) 三村耕, 森田琭磨（1980）; 家畜管理学, 養賢 堂, 東京.

9 ) Simesen, E. (1974); The relationship between weather and incidence of parturient and mastitis in dairy cows, Nord. Vet. Med.26,382 -386 .

10) Walser, V. K., Bieber, E., Dannerbeck, G., Gropper, M., Hropot, M., Lankenfeld, H., Mayer, J., Vergho, H. and Viktor, M., (1972) ; Clinical contribution to the knowledge of acute mastitis in cows.III. influence of climate., Vet. Rec.,17,330-333.

11）安井一夫, 三浦亮二, 山崎幸男 (1976) ; 乳牛の 飼養規模別繁殖実態調査 (第 2 報), 紫葉, 21 , $79-84$.

\section{要 約}

千葉県農業共済組合連合会家畜臨床研修所管内の 酪農家69戸について, 昭和 55 年度から 57 年度の疾病 のリ患率および同地区における気象要因を調査し，
疾病のリ患率と気象要因の相関関係を調べた。さら に对象酪農家の経営, 飼養および環境等に関する項 目を調查し得られた調査結果をもとに, 数量化理論 III類によって抽出した主要な項目と疾病のリ患率と の関連性を, 数量化理論 I 類によって重相関分析し 以下の結果を得た。

1.「全疾病」および「乳房炎」の月別り患率は, 一 般に月別の平均気温および月別の平均湿度との間に 強い正の相関 $(\mathrm{P}<0.05)$ を示したが,「産科疾患」 およU゙「不妊症」のリ患率は，これらの気象要因と 有意の相関を示さなかった。すなわち, 疾病の種類 によって，そのリ患率におよぼす気温，気湿などの 気象要因の影響力は異なるものと思われた。

2.「全疾病」のリ患率と酪農環境要因との関連性 を, 数量化理論 I 類で分析した結果, 「全疾病」のリ 患率は, 酪農専業度が高く, 規模が大きく, 生産意 欲の旺盛な若い経営者が経営している酪農家で高い 傾向がみられた。

3.「産科疾患」のリ患率は, 他の疾病にくらべ経営 に関する事項との関連の度合が高く, 特に経営者の 年令および後継者の有無がリ患率の大きさに強く影 響しており, 経験豊富な高齢の経営者でリ患率が低 い傾向がみられた。

4.「不妊症」のリ患率は, 牛舎の環境と構造および 経営に関する事項との関連が強く, 牛舎環境が悪い 場合にリ患率が増加する傾向を示した。また, 経営 者が若く, 目標乳量の高い専業酪農家においてリ患 率が高いように思われた。

5.「乳房炎」のリ患率は, 牛舎の環境と構造に関す る事項, とくに排水溝の構造と飼槽の形式との関連 が大きかった。また，規模が大きく目標乳量の高い 酪農家において、リ患率が高い傾向を示した。 